\title{
Використання дистанційного методу термографії для діагностики глибини дермальних опіків
}

\begin{abstract}
Мета роботи: оцінити можливість використання методу безконтактної термографії для визначення глибини опікового ураження за допомогою медичного тепловізора ULIRVISION T1-120.

Матеріали і методи. Проведено аналіз результатів термографічного дослідження ранових опікових поверхонь 3 ураженням шкіри I-III ступенів, використовуючи метод безконтактного визначення глибини термічних уражень за допомогою медичного тепловізора ULIRVISION T1-120. Обстежено 63 пацієнти з дермальними опіками I-III ступеня. Термограми аналізували за допомогою програмного пакета “IRSee Software”.

Результати досліджень та їх обговорення. Вперше в Україні з використанням тепловізора ULIRVISION T1-120 встановлено статистичну достовірність між значеннями середньої температури та глибиною ураження шкіри при різних ступенях опіків. Термографічні вимірювання були отримані впродовж перших двох діб від отримання травми (середній час $26 \pm 3,1$ год, медіана 18 год). Середня температура рани I ст. становила $(35,23 \pm 0,31)^{\circ} \mathrm{C}$, II ст. - $(31,20 \pm 0,49){ }^{\circ} \mathrm{C}$, III ст. $-(29,31 \pm 0,52){ }^{\circ} \mathrm{C}$. Середня температура тіла в контрольній групі - $(33,11 \pm 0,38){ }^{\circ} \mathrm{C}$. Показник різниці температури між ураженою ділянкою та здоровою шкірою $\Delta \mathrm{T}$ при I ст. опіків складав $(1,3 \pm 0,6){ }^{\circ} \mathrm{C}$, при II ст. $-(2,1 \pm 1,1){ }^{\circ} \mathrm{C}$, при III ст. $-(3,2 \pm 1,6){ }^{\circ} \mathrm{C}$. Встановлено достовірність між показниками середньої температури у групах пацієнтів з I, II та III ступенями дермальних опіків.
\end{abstract}

Ключові слова: термометрія; перепад температури; глибина опіків.

Постановка проблеми і аналіз останніх досліджень та публікацій. Опіки є четвертим за поширеним видом травм у всьому світі після дорожньо-транспортних пригод, падінь та міжособистісного насильства. Всесвітня організація охорони здоров’я вважає цей вид травми глобальною проблемою сьогодення, яка щорічно спричиняє 300000 смертей у всьому світі [1]. Високий рівень ендогенної інтоксикації у пацієнтів з тяжкою термічною травмою, високий ризик розвитку ускладнень та життєвих дисфункцій, що, у свою чергу, залежить від площі та глибини опікових уражень, тому і прогноз більшою мірою залежить від площі та глибини уражень. Чим більша площа уражень шкірних покривів та глибини опікової рани, тим тяжчий прогноз перебігу захворювання (Братусь В. Д.).

Клінічна оцінка опікової рани часто $є$ недостатньою для прогнозування тяжкості захворювання. Суб'єктивна оцінка зорових і тактильних характеристик достовірна лише в 50-70 \% випадків й залежить від кваліфікації лікаря [2,3]. Вперше прогностичне значення термографії для опіків було запропоновано ще у 1961 р. [5]. Проте через десять років дана методика випробувана на великій серії хворих з опіками [6]. Це дослідження продемонструвало перевагу термометрії (90 \%) над клінічною оцінкою (75 \%). 3 того часу було проведено багато досліджень з використанням широкого спектра тепловізорів. Проте громіздкі параметри та низька роздільна здатність обладнання пере- шкоджали використанню термографії в клінічній практиці. Новітні технологічні досягнення створили менші, швидші та доступніші тепловізори.

Для визначення глибини опікового ураження використовують метод візуалізації термічних уражень неврологічної симптоматики, характерної для глибокого та поверхневого опікового ураження. У різних опікових ураженнях метод титрациклінової флуоресценції, метод термометрії, ферментний метод.

Одним із об'єктивних методів, які часто застосовують для оцінки глибини опіку та вибору тактики ведення пацієнта, є цифрова інфрачервона термографія. Дослідження надає важливу інформацію про життєздатність м'яких тканин, візуалізує ступінь їх ушкодження і може кількісно оцінити глибину опіку на основі отриманих цифрових зображень [4]. Перевагами цифрової термографії $€$ її неінвазивність, неболючість і безконтактність, що виключає ризик тиску на рану, який може вплинути на мікроциркуляцію та ï̈ контамінацію.

За даними науковців, термографія $є$ важливим інструментом для оцінки опікових ран на різних стадіях [7]. Пріоритетними $є$ дослідження використання цього методу для визначення способу лікування, таким чином запобігаючи затримці хірургічного втручання.

Золотим стандартом для верифікації глибини ушкодження шкіри залишається біопсія з морфологічним дослідженням, але травматичність цього 
методу та помилки при відборі проб не завжди дають змогу використовувати, зважаючи на тяжкість комбустіологічного хворого, неможливість проводити його в динаміці. Окрім того, це інвазивна процедура, яка викликає додаткові рубці та збільшує ризик зараження рани. Також для валідної інтерпретації результатів біопсії потрібен досвідчений патолог.

Сьогодні у комбустіології використовують сучасні методи визначення глибини уражень: метод вітальних барвників, відеомікроскопію, лазерну доплерогафію. Хоча остання з методик - єдина техніка неінвазивної оцінки опікових ран затверджена Управлінням з контролю за продуктами та ліками США: висока вартість її придбання та обслуговування, потреба у кваліфікованому персоналі для експлуатації обладнання та інтерпретування зображень, відносно тривалий час сканування рани, необхідна седація педіатричних хворих, щоб отримати якісні зображення, обмежують використання лазерної доплерографії у повсякденній практиці [8].

Доступним методом для визначення глибини термічного ураження, вважається безконтактна термографія [15]. Дослідження показали, що руйнування судин під час ушкодження шкіри викликає зменшення місцевої перфузії та вторинне зниження температури шкіри в цій ділянці [9]. Порушеня кровообігу корелює із ступенем травми і відображається у вигляді кольорової термограми. Отримане зображення використовують для вимірювання температури шкіри на різних ділянках і обчислення дельта-Т $(\Delta \mathrm{T})$, що показує різницю в температурі між місцем рани та сусідньою здоровою ділянкою шкіри [10]. Це значення є надійним показником статичної візуалізації та корелює 3 життєздатністю тканин [11].

Актуальність дослідження підтверджує той факт, що в комбустіології ще не складено єдиного алгоритму для визначення глибини термічного ураження шкіри. Прицільна і точна оцінка глибини термічного ушкодження має вирішальне значення для вибору індивідуалізованої тактики лікування обпеченого хворого. Найбільш ефективним залишається методика мультимодальних підходів у діагностиці глибини термічних уражень.

Мета роботи: оцінити можливість використання методу безконтактної термографії для визначення глибини опікового ураження за допомогою медичного тепловізора ULIRVISION T1-120.

Матеріали і методи. Проведено аналіз результатів термографічного дослідження ранових опікових поверхонь з ураженням шкіри I-III ступенів, використовуючи метод безконтактного визначення глибини термічних уражень за допомогою медичного тепловізора ULIRVISION T1-120. Обстежено 63 пацієнти з дермальними опіками I-III ст., що були госпіталізовані у центр термічної травми та пластичної хірургії КНП «8-а міська клінічна лікарня м. Львова». Чоловіків було - 41 (65,0 \%),

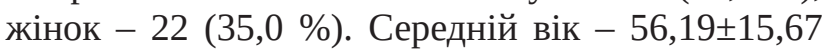
року. В дослідження не включали хворих із судинними захворюваннями, хімічними видами опіків, наявністю сторонніх тіл у рані, вираженим набряком ушкодженої ділянки, наявністю місцевої інфекції. Перед візуалізацією рану очищали розчином хлоргексидину $0,05 \%$. Опікова поверхня була сухою для запобігання випаровуванню вологи та тепловтрат. У палаті, де проводили термографічні дослідження, витримували постійний температурний режим $22{ }^{\circ} \mathrm{C}$ та відносну вологість повітря від 40 \%, екранували активні джерела тепла, домагалися відсутності повітряних потоків.

Термографічну зйомку дермального опіку проводили в положенні хворого сидячи або стоячи під кутом 90, прилад фокусували на відстані 40-100 см, залежно від того, яка відстань була найкращою, щоб охопити всю площу ураження. Зонами інтересу були опікові поверхні, зона еритеми і прилеглих тканин, а при ураженні парної ділянки (кінцівки, бокові поверхні тулуба) - ще й симетрична частина тіла. Спрямовували пристрій на дермальний опік вимірювання та налаштовували на правильний фокус.

Для визначення особливостей інфрачервоного випромінювання у нормі були обстежені 45 здорових волонтерів 3 нормальною температурою тіла, які не мали органічної патології шкіри та внутрішніх органів, віком від 19 до 57 років, середній вік - $(34,4 \pm 6,5)$ року. 3 них 25 чоловіки, що склало 57,1 \%, і 20 жінок - 42,9 \%, середній вік з урахуванням статі виявився приблизно однаковим, у чоловіків - $(34,9 \pm 7,2)$ року, у жінок - $(33,7 \pm 7,8)$ року.

Термограми аналізували за допомогою програмного пакета "IRSee Software” (рис. 1). Tермозображення оцінювали візуально шляхом порівняння колірної палітри з прилеглими ділянками, а за наявності термоасиметрії термограми описували за таким алгоритмом: термоасиметрія; локалізація зони з підвищеною і зниженою інтенсивністю інфрачервоного випромінювання; температурні значення та їх різниця зі симетричною зоною. Величини температур в усіх точках зображення програма фіксує автоматично. Для більшої інформативності використовували побудову термографіків, гістограм. Подібна методика $€$ прецизійною і дає змогу представити розподіл 


\section{З ДОСВІДУ РОБОТИ}

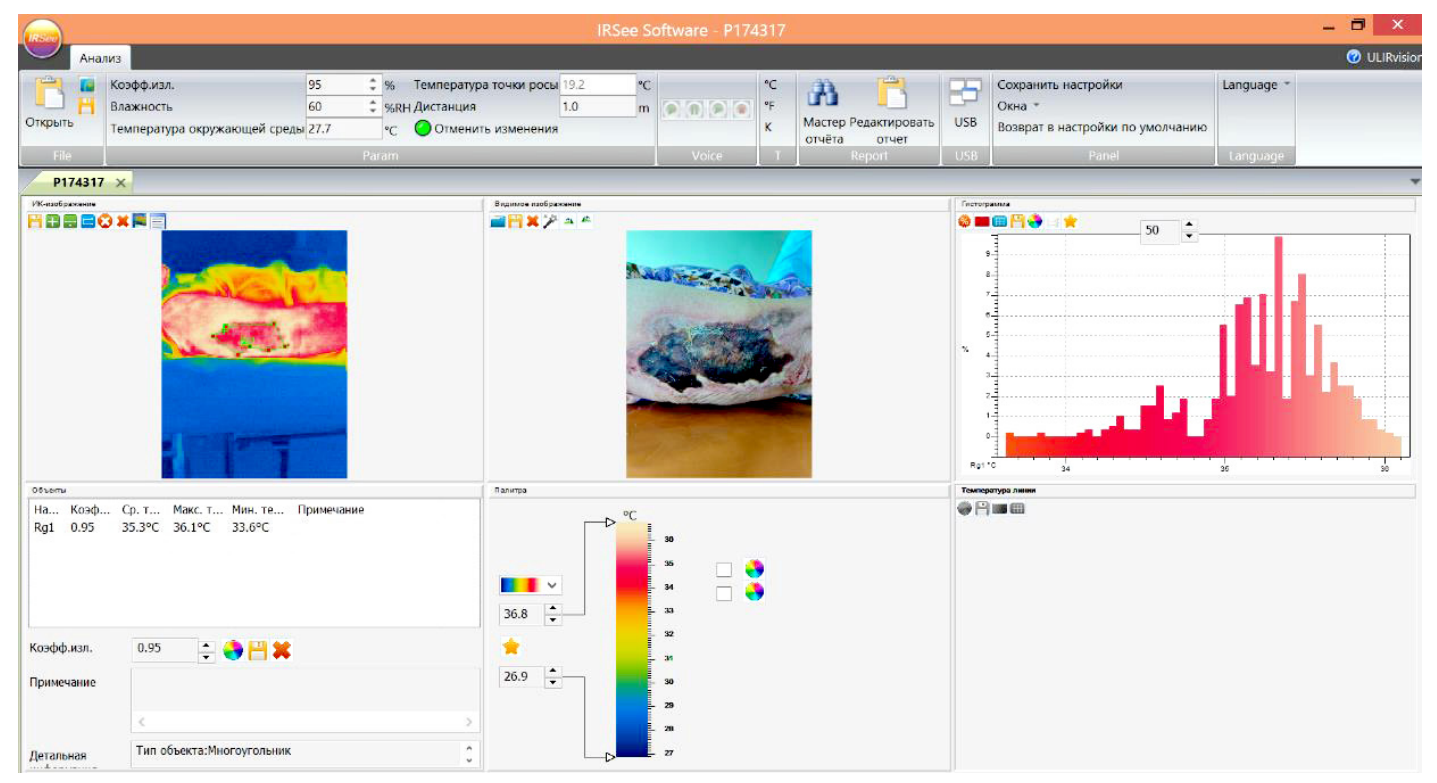

Рис. 1. Аналіз термограми пацієнтки П., 78 р., із термічним опіком II ступеня у програмі “IRSee Software”.

температур не лише в загальному регіоні, але й у певних точках. При оцінці термограм брали до уваги дані протоколу Гламоргана, щоб уникнути помилок при оцінюванні симетричних ділянок [12]. При аналізі зони інтересу враховували форму термоактивної ділянки (вогнищева, розлита), iï структуру за ступенем однорідності (гомогенна, гетерогенна), особливості контурів (чіткі, нечіткі), топографічна відповідність зони інтересу і локалізації патологічного вогнища.

Оброблені термограми зберігали в електронному архіві, для наступного порівняння при спостереженні хворого в динаміці. Програма “IRSee Software” дає змогу детально аналізувати теплові зображення за допомогою характеристик обраних точок, ліній (довільної, горизонтальної, вертикальної та багаторядкового аналізу), а також поля (прямокутного, еліптичного та полігонального). Щоб порівняти між собою симетричні ділянки чи вогнище розігріву з довколишніми тканинами, ми використовували передусім опцію точок, горизонтальної лінії та прямокутного поля. У такому випадку фіксувалася температура позначених точок, що дало змозу вирахувати використовувану надалі різницю температур $(\Delta \mathrm{T})$, всієї лінії інтересу з автоматичним зазначенням екстремальних значень (максимальної і мінімальної температури), а обране прямокутне поле забезпечувало автоматичну побудову гістограми, що наочно демонструвало розподіл масиву температур від мінімальної до максимальної. Для всіх отриманих вимірювань коефіцієнт випромінювання шкіри становив 0,96.
На момент запису нормальна температура шкіри у всіх пацієнтів була афебрильна.

Статистичну обробку проводили за допомогою комп’ютерних програм “Microsoft Office Excel” i “STATISTICA”.

Результати досліджень та їх обговорення. Серед 63 пацієнтів опіки I ст. були у 15 (23,8 \%), II ст. - у 27 (42,9 \%), III ст. - 21 (33,3 \%). Термічні ураження спостерігали у 59 (93,7 \%) осіб, із них у 36 (57,1 \%) хворих причиною стало ошпарення окропом, у 23 (36,5 \%) обпалення полум’ям. Залежно від площі опікової поверхні пацієнти розподілились так: ураження $<10,0 \%$ площі тіла було 34 (53,9 \%) осіб, від 10,0 \% до 30,0 \% - у 21 (33,3 \%), > 30,0 \% - у 7 (11,1 \%) хворих. Розподіл за локалізацією опікової рани зображений на рисунку 2.

Термографічні вимірювання були отримані впродовж перших двох діб від отримання травми (середній час $26 \pm 3,1$ год, медіана 18 год). Середня температура рани I ст. становила $35,23 \pm 0,31{ }^{\circ} \mathrm{C}$, II ст. $-31,20 \pm 0,49{ }^{\circ} \mathrm{C}$, III ст. $-29,31 \pm 0,52{ }^{\circ} \mathrm{C}$. Ceредня температура тіла в контрольній групі 33,11 $\pm 0,38{ }^{\circ} \mathrm{C}$. Показник різниці температури між ураженою ділянкою та здоровою шкірою $\Delta \mathrm{T}$ при I ст. опіків складав $1,3 \pm 0,6{ }^{\circ} \mathrm{C}$, при II ст. 2,1 $\pm 1,1{ }^{\circ} \mathrm{C}$, при III ст. $-3,2 \pm 1,6^{\circ} \mathrm{C}$.

Встановлено достовірність між показниками середньої температури у групах пацієнтів з I, II та III ступенями дермальних опіків, а також при їх порівнянні із контрольною групою (табл. 1). 


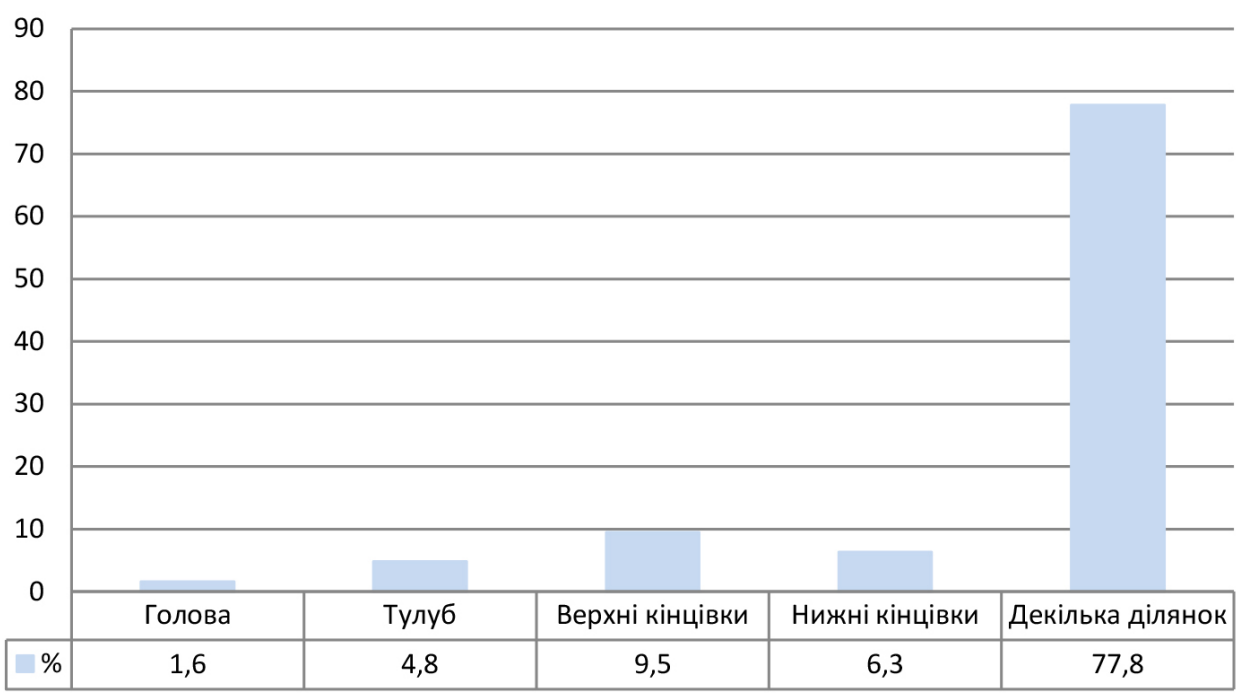

Рис. 2. Локалізація опікових ран.

Таблиця 1. Результати термографічного дослідження пацієнтів

\begin{tabular}{|c|c|c|c|c|c|}
\hline & I ст. $(n=15)$ & II ст. (n=27) & III cT. (n=21) & Контрольна група (n=45) & Тест Тьюкі \\
\hline $\begin{array}{l}\text { Середня } \\
\text { температура } \\
\text { опікової рани }{ }^{\circ} \mathrm{C}\end{array}$ & $35,23 \pm 0,31$ & $31,20 \pm 0,49$ & $29,31 \pm 0,52$ & $33,11 \pm 0,38$ & $\begin{array}{l}\mathrm{p}_{1-2}<0,001^{*} \\
\mathrm{P}_{1-3}<0,001^{*} \\
\mathrm{P}_{1-\mathrm{K}}<0,001^{*} \\
\mathrm{P}_{2-3}<0,001^{*} \\
\mathrm{P}_{2-\mathrm{K}}<0,001^{*} \\
\mathrm{P}_{3-\mathrm{K}}<0,001^{*}\end{array}$ \\
\hline
\end{tabular}

Примітка. * - статистично достовірні результати.

Незважаючи на те, що у літературі зустрічаються дані про залежність $\Delta \mathrm{T}$ між площею опіку та термічним видом травми, при подальшому статистичному аналізі достовірності між $\Delta \mathrm{T}$ та такими факторами, як вік, стать, загальна площа та етіологія опіку не встановлено.

Враховуючи дані, отримано при зіставлені методів термографії з біопсією та лазерною доплерогафією, які показали високу валідність цього методу [13, 14], ми порівняли метод візуалізації 3 даними, отриманих з термограм (табл. 2).

Чотири випадки, які клінічно були оцінені як опіки II ст., відповідали термографічній картині III ст., що внесло корективи в подальшу лікувальну тактику даних пацієнтів.

Наші дані збігаються 3 дослідженнями науковців і підтверджують зниження середньої температури та збільшення $\Delta \mathrm{T}$ при збільшенні глибини опіку.

Таблиця 2. Порівняння візуалізаційного та термографічного методів

\begin{tabular}{||c|c|c|c|c||}
\hline \multirow{2}{*}{ Ступені } & \multicolumn{2}{|c|}{ Візуалізаційний метод } & \multicolumn{2}{c||}{ Термографічнй метод } \\
\cline { 2 - 5 } & $\mathrm{n}$ & $\%$ & $\mathrm{n}$ & $\%$ \\
\hline I ст. & 15 & 23,8 & 27 & 42,8 \\
\hline II ст. & 31 & 49,2 & 21 & 33,3 \\
\hline III ст. & 17 & 27,0 & 63 & - \\
\hline Всього & 63 & - & 27 \\
\hline
\end{tabular}




\section{З ДОСВІДУ РОБОТИ}

В Україні є деякі напрацювання щодо використання методу інфрачервоної термографії при опіках [15], проте достовірність перепаду температури порівняно між ступенем глибини ураження та зіставленні отриманих даних зі контрольною групою пацієнтів отримано вперше.

Висновки. Вперше в Україні з використанням тепловізора ULIRVISION T1-120 встановлено статистичну достовірність між значеннями середньої температури та глибиною ураження шкіри при різних ступенях опіків. Достовірно продемонстрова- но переваги застосування термографії порівняно 3 візуалізаційним методом діагностики опікових ран.

Перспективи подальших досліджень. Інфрачервона термографія може бути використана як незалежний прогностичний фактор клінічних результатів загоєння опікової рани (дослідження тривають). Також це перспективна техніка, що може використовуватись для сортування опікових пацієнтів на різних етапах надання медичної допомоги. Методика $€$ цінним доповнення до клінічної оцінки в опікових центрах.

\section{СПИСОК ЛІТЕРАТУРИ}

1. WHO | Burns [Internet]. WHO. [cited 2017 May 18]. - Access mode : http://www.who.int/mediacentre/factsheets/fs365/en/ 2. Noninvasive imaging technologies for cutaneous wound assessment: A review / D. W. Paul, P. Ghassemi, J. C. Ramella-Roman [et al.] // Wound Repair Regen off Publ. Wound Heal Soc. Eur. Tissue Repair Soc. - 2015. - Vol. 23 (2). - P. 149-156.

3. Critical Review of noninvasive optical technologies for wound imaging / M. Jayachandran, S. Rodriguez, E. Solis [et al.] // Adv. Wound Care. - 2016. - Vol. 5 (8). - P. 349-359.

4. Forward-looking infrared imaging predicts ultimate burn depth in a porcine vertical injury progression model / J. Miccio, S. Parikh, X. Marinaro [et al.] // Burns J. Int. Soc. Burn. Inj. 2016. - Vol. 42 (2). - P. 397-404.

5. Lawson R. N. Thermographic assessment of burns and frostbite / R. N. Lawson, G. D. Wlodek, D. R. Webster // Can. Med. Assoc. J. - 1961. - Vol. 84. - P. 1129-1131.

6. Hackett M. E. The use of thermography in the assessment of depth of burn and blood supply of flaps, with preliminary reports on its use in Dupuytren's contracture and treatment of varicose ulcers / M. E. Hackett // Br. J. Plast. Surg. - 1974. - Vol. 27 (4). - P. 311-317.

7. Noninvasive assessment of burn wound severity using optical technology: a review o current and future modalities / M. Kaiser, A. Yafi, M. Cinat [et al.] // Burns J. Int. Soc. Burn. Inj. - 2011. Vol. 37 (3). - P. 377-386.

8. Infrared thermal imaging has the potential to reduce unnecessary surgery and delays to necessary surgery in burn patients / A. J. Singer, P. Relan, L. Beto [et al.] // J. Burn Care Res. - 2016.

\section{REFERENCES}

1. WHO | Burns [Internet]. WHO. [cited 2017 May 18]. Retrieved from: http://www.who.int/mediacentre/factsheets/ fs365/en/.

2. Paul, D.W., Ghassemi, P., Ramella-Roman, J.C., Prindeze, N.J., Moffatt, L.T., \& Alkhalil, A. (2015). Noninvasive imaging technologies for cutaneous wound assessment: A review. Wound Repair Regen off Publ. Wound Heal Soc. Eur. Tissue Repair Soc., 23 (2), 149-146.

3. Jayachandran, M., Rodriguez, S., Solis, E., Lei, J., \& Godavarty, A. (2016). Critical review of noninvasive optical technologies for wound imaging. Adv. Wound Care. 1; 5(8), 349-359.

4. Miccio, J., Parikh, S., Marinaro, X., Prasad, A., McClain, S., \& Singer, A.J. (2016). Forward-looking infrared imaging predicts
- Vol. 37 (6). - P. 350-355.

9. Diagnosis of burn depth using laser-induced Indocyanine green fluorescence: A preliminary clinical trial / J. M. Still, E. J. Law, K. G. Klavuhn [et al.] // Burns. - 2001. - Vol. 27. P. 364-371.

10. Thermography-based blood flow imaging in human skin of the hands and feet: a spectral filtering approach / A. A. Sagaidachnyi, A. V. Fomin, D. A. Usanov, A. V. Skripal // Physiol. Meas. - 2017. - Vol. 38 (2). - P. 272-288.

11. Insights into the use of thermography to assess burn wound healing potential: a reliable and valid technique when compared to laser Doppler imaging / M. E. H. Jaspers, I. Maltha, J. H. G. M. Klaessens // J. Biomed. Opt. - 2016. - Vol. 21 (9). - P. 960-906.

12. Ammer K. The Glamorgan Protocol for recording and evaluation of thermal images of the human body / K. Ammer // Thermol. Int. - 2008. - Vol. 18. - P. 125-144.

13. Validity of thermography for measuring burn wound healing potential / M. E. Carrière, L. E. M. de Haas, A. Pijpe [et al.] // Wound Repair and Regeneration: Official Publication of the Wound Healing Society [and] the European Tissue Repair Society. - 2020. - Vol. 28 (3). - P. 347-354.

14. Thermometry: A simple objective method for burn depth assessment / P. Agarwal, D. Sharma, S. Wankhede, L. K. Patel // Indian J. Burns. - 2018. - Vol. 26. - P. 72-76.

15. Коваленко А. О. Застосування термометрії для визначення глибини дермальних опіків / А. О. Коваленко // Клінічна хірургія. - 2015.- № 4. - С. 66- 68. ultimate burn depth in a porcine vertical injury progression model. Burns J. Int. Soc. Burn Inj., 42 (2), 397-404.

5. Lawson, R.N., Wlodek, G.D., \& Webster, D.R. (1961). Thermographic assessment of burns and frostbite. Can. Med. Assoc. J., 84, 1129-1131.

6. Hackett, M.E. (1974). The use of thermography in the assessment of depth of burn and blood supply of flaps, with preliminary reports on its use in Dupuytren's contracture and treatment of varicose ulcers. Br. J. Plast. Surg., 27 (4), 311-317.

7. Kaiser, M., Yafi, A., Cinat, M., Choi, B., \& Durkin, A.J. (2011). Noninvasive assessment of burn wound severity using optical technology: a review of current and future modalities. Burns J. Int. Soc. Burn Inj., 37 (3), 377-386. 


\section{З ДОСВІДУ РОБОТИ}

8. Singer, A.J., Relan, P., Beto, L., Jones-Koliski, L., Sandoval, S., \& Clark, R.A. (2016). Infrared thermal imaging has the potential to reduce unnecessary surgery and delays to necessary surgery in burn patients. J. Burn Care Res. 37 (6), 350-355.

9. Still, J.M., Law, E.J., Klavuhn, K.G., Island, T.C., \& Holtz, J.Z. (2001). Diagnosis of burn depth using laser-induced Indocyanine green fluorescence: A preliminary clinical trial. Burns, 27, 364-371.

10. Sagaidachnyi, A.A., Fomin, A.V., Usanov, D.A., \& Skripal, A.V. (2017). Thermography-based blood flow imaging in human skin of the hands and feet: a spectral filtering approach. Physiol. Meas, 38 (2), 272-288.

11. Jaspers, M.E.H., Maltha, I., Klaessens, J.H.G.M., de Vet H.C.W., Verdaasdonk, R.M., van Zuijlen, P.P.M. (2016). Insights into the use of thermography to assess burn wound healing potential: a reliable and valid technique when compared to laser

Електронна адреса для листування: zaporozhan@tdmu.edu.ua
Doppler imaging. J. Biomed. Opt., 21 (9), 960-906.

12. Ammer, K. (2008). The Glamorgan Protocol for recording and evaluation of thermal images of the human body. Thermol. Int., 18, 125-144.

13. Carrière, M.E., de Haas, L.E.M., \& Pijpe, A. (2020). Validity of thermography for measuring burn wound healing potential. Wound Repair and Regeneration: Official Publication of the Wound Healing Society [and] the European Tissue Repair Society, 28 (3), 347-354.

14. Agarwal, P., Sharma, D., Wankhede, S., \& Patel, L.K. (2018). Thermometry: A simple objective method for burn depth assessment. Indian J. Burns, 26, 72-76.

15. Kovalenko, A.O. (2015). Zastosuvannia termometrii dlia vyznachennia hlybyny dermalnykh opikiv [Application of thermometry to determine the depth of dermal burns]. Klinichna khirurhiia. - Clinical Surgery, 4, 66-68 [in Ukrainian].

Отримано 12.07.2021

N. V. TUZYUK, S. Y. ZAPOROZHAN, M. T. HUK

I. Horbachevsky Ternopil National Medical University

\section{DISTANT THERMOGRAPHY METHODS FOR DIAGNOSIS OF DERMAL BURNS DEPTH}

The aim of the work: to assess the possibility of using the method of non-contact thermography to determine the depth of a burn injury using a medical thermal imager ULIRVISION T1-120.

Materials and Methods. The analysis of the results of thermographic study of wound burn surfaces with stage I-II-III skin lesions, using the method of non-contact determination of the depth of thermal lesions using a medical thermal imager ULIRVISION T1-120, was performed. There were examined 63 patients with degree I-III dermal burns. Thermograms were analyzed using the IRSee Software package. Results and Discussion. For the first time in Ukraine, using the ULIRVISION T1-120 thermal imager, statistical reliability was established between the values of the average temperature and the depth of skin lesions at various degrees of burns. Thermographic measurements were obtained within the first two days after injury (mean time $26 \pm 3.1 \mathrm{~h}$, median $18 \mathrm{~h}$ ). Average temperature of the stage I wound was $(35.23 \pm 0.31)^{\circ} \mathrm{C}$, stage II $-(31.20 \pm 0.49)^{\circ} \mathrm{C}$, stage III $(29.31 \pm 0.52)^{\circ} \mathrm{C}$. Average body temperature in the control group $-(33.11 \pm 0.38)$ ${ }^{\circ} \mathrm{C}$. Indicator of the temperature difference between the affected area and healthy skin $\Delta \mathrm{T}$ at stage $\mathrm{I}$ burns was (1.3 \pm 0.6$)^{\circ} \mathrm{C}$, stage II $(2.1 \pm 1.1)^{\circ} \mathrm{C}$, stage III $-(3.2 \pm 1.6)^{\circ} \mathrm{C}$ The reliability was established between the average temperature values in the groups of patients with degrees I, II and III of dermal burns.

Key words: thermometry; temperature drop; burns depth. 